\title{
Insulin-Like Activity and Immunoreactive Insulin Content of Gel-Filtered Protein Fractions of Bovine Serum*
}

\author{
W. KoniJnendiuk and P.R. Bouman \\ Department of Pharmacology, University of Groningen, The Netherlands
}

Received: February 10, 1969

\begin{abstract}
Summary. Serum globulin fractions isolated by gel filtration from fasting bovine sera with simultaneous ex. clusion of low molecular endogenous immunoreactive insulin (IRI), were found to contain immunoreactive insulin-like material in quantities which equal or surpass the directly assayable IRI content of native fasting sera. In one additional and clearly aberrant serum, independently isolated globulin fractions were found to contain $306 \mu \mathrm{U}$ of IRI per $\mathrm{ml}$ of serum, and appeared to exert an equivalent antibody-suppressible insulin-like activity (ILA) on rat adipose tissue in vitro. The IRI content of the native serum amounted to $15 \mu \mathrm{U} / \mathrm{ml}$ and its suppressible ILA content to $46 \mu \mathrm{U} / \mathrm{ml}$. The presence of insulin-binding antibodies and accidental contamination with crystalline insulin could be excluded. It is suggested that in addition to low molecular IRI which reflects the insulin response to glucose loading, normal bovine serum may contain small basal levels of a high molecular globulin-associated form of IRI, which may be subject to pathologic elovation.
\end{abstract}

Contenu en activité insulinique (ILA) et en insuline immunoréactive (IRI) de fractions protéiniques isolées par filtration sur gel à partir de sérum de boeuf

Résumé. Des fractions globuliniques du sérum ont été isolées par filtration sur gel à partir de 10 sérums de boeuf à jeun, avec exclusion simultanée de l'insuline immunoréactive endogène de faible poids moléculaire (IRI). On a trouvé que ces fractions contenaient du matériel immunoréactif semblable à l'insuline en quantités égales ou dépassant le contenu en IRI directement dosable de sérums naturels à jeun. Dans un sérum supplémentaire et nettement aberrant, on a trouvé que des fractions globuliniques isolées indépendamment contenaient $306 \mu \mathrm{U}$ d'IRI par mil de sérum et exerçaient une activité insulinique (ILA), supprimable par les anticorps, équivalente, sur le tissu adipeux du rat in vitro. Le contenu en IRI du sérum naturel était de $15 \mu \mathrm{U} / \mathrm{ml}$ et son contenu. en ILA sup- primable était de $46 \mu \mathrm{U} / \mathrm{ml}$. La présence d'anticorps liant l'insuline et une contamination accidentelle avec de l'insuline cristalline ont pu être exclues. Il est suggéré qu'en plus de l'IRI de faible poids moléculaire qui reflète la réponse de l'insuline à une charge en glucose, le sérum normal de boeuf peut contenir de faibles taux de base d'une forme d'IRI associée aux globulines de poids moléculaire élevé, qui peut être sujette à une élévation pathologique.

Insulinähnliche Aktivität und immunoreaktives Insulin in gelfiltrierten Eiweißfraltionen von Rinderserum

Zusammenfassung. Globulinfraktionen wurden aus 10 Seren von nüchternen Rindern durch Gelfiltration isoliert unter gleichzeitigem Ausschluß von kleinmolekularem endogenem immunoreaktivem Insulin (IRI). In diesen Fraktionen wurde immunoreaktive-insulinähnliche Aktivität nachgewiesen in Quantitäten, welche sich dem direkt meßbaren IRI-Gehalt von nativ nüchteren Seren annähern oder ihn übertreffen. In einem zusätzlichen und deutlich abweichenden Serum zeigten unabhängig voneinander isolierte Globulinfraktionen einen Gehalt von $306 \mu \mathrm{E}$ IRI pro ml Serum, und wurde eine gleichwertige, antikörperhemmbare insulinähnliche Aktivität am Fettgewebe der Ratte in vitro nachgewiesen. Der IRI Gehalt des nativen Serums betrug $15 \mu \mathrm{E}$ und sein Gehalt an hemmbarer ILA $46 \mu \mathrm{E}$ pro ml. Die Gegenwart von insulinbindenden Antikörpern und eine zufällige Verunreinigung mit Kristallinsulin konnten ausgeschlossen werden. Die Daten lassen annehmen, daß außer dem kleinmolekularen IRI, welches die Insulinreaktion auf Glucosebelastung darstellt, normales Rinderserum geringe Basalspiegel einer großmolekularen globulinassoziierten Form von IRI enthalten kann, welche pathologisch erhöht sein kann.

Key-words: Endogenous immunoreactive insulin, total and suppressible IL $\AA$, gel filtration, serum protein fractions, high molecular immunoreactive insulin-like substance.

\section{Introduction}

Ultracentrifugation studies suggest that endogenous insulin is predominantly contained in plasma as a low molecular weight substance, directly assayable by radioimmunologic procedures $[5,8,13]$. These and various other observations have cast considerable doubt on the existence of a protein-bound form of insulin in blood, that would escape detection by radioimmunoassay as might be inferred from studies re-

* This work was supported by a grant from the Netherlands Organisation for the Advancement of Pure Research (Z.W.O.). ported by Antoniades et al. [1]. Moreover, attempts by various investigators to increase the immunoreactive insulin (IRI) content of serum or serum protein fractions by various forms of treatment have remained unsuceessful so far $[2,4,8,13,14]$.

Since this controversial issue remains essentially a problem of molecular size, biologic and immunologic assays were performed on serum protein fractions obtained by gel filtration of bovine sera on Sephadex G-100 with simultaneous exclusion of low molecular weight endogenous insulin. Except for the recent study of Kajinuma et al. [12], systematic studies of this kind have not been reported. 
The following minimum criteria for endogenous insulin were adopted: 1 . detectability by radioimmunoassay. 2. parallel-line response against a crystalline insulin standard in the rat adipose tissue assay. 3. suppression of biologic activity in the adipose tissue assay by excess anti-insulin serum.

\section{Material and Methods}

Sera and separation procedure. The peripheral sera used in this study were obtained from individual cows at the local slaughter-house. Bovine pancreatic venous serum was obtained by canulation of a pancreatic vein following laparotomy under local anaesthesia. Blood was collected in centrifuge bottles and allowed to clot for $2 \mathrm{~h}$ at room temperature. The serum was separated by centrifuging at 2700 r.p.m. for $20 \mathrm{~min}$ and divided into samples of $11 \mathrm{ml}$ each, which were frozen and stored at $-25^{\circ} \mathrm{C}$. All experiments were conducted on samples which had been frozen and thawed only once.

Fractionation of the sera was accomplished by gel filtration of $4-5 \mathrm{ml}$ of serum on Sephadex G-100 columns (bed-size $38 \times 2.5 \mathrm{~cm}$ ) at $+4^{\circ} \mathrm{C}$. Elution was performed with a peristaltic pump at a rate of $25 \mathrm{ml}$ per hour.

a) Pilot experiments were carried out to test the ability of the columns to separate endogenous insulin (pancreatic venous serum) or added crystalline insulin from the fractions containing high molecular weight proteins. The columns were equilibrated and eluted with veronal buffer (ionic strength 0.1 and $\mathrm{pH} 8.5$ ) containing $0.025 \%$ bovine serum albumin. Fractions varying between 3.75 and $4 \mathrm{ml}$ were collected by photoelectric drop counting, and individually measured for optical density and the presence of immunoreactive material.

b) In the serial experiments serum fractions were obtained from $10 \mathrm{ml}$ of serum by separation on two columns, which were run simultaneously. To allow direct bioassay of combined wet fractions, the columns were equilibrated and eluted with Krebs-Ringer bicarbonate solution [17] at $\mathrm{pH}$ 7.4. Eluates from both columns were pooled on the basis of the optical density readings to form two high molecular weight fractions which predominantly contained globulins and albumin.

From most of the sera to be tested, duplicate pools were prepared for assay in the wet state and following freeze-drying. In the latter case the two fractions were lyophilized immediately following separation and subsequently dialyzed for $48 \mathrm{~h}$ against water in Visking tubing $18 / 32 \mathrm{at}+4^{\circ} \mathrm{C}$. The dialysed fractions were then lyophilized again and stored until further use.

Bioassay. Total and antibody-suppressible insulinlike activity (ILA) on rat adipose tissue in vitro were determined by the slightly modified method of Steelman $e t a l$. [16], glucose uptake serving as the parameter for insulin-like activity. Epididymal fat tissue (90-100 $\mathrm{mg}$ per vessel) from a tissue pool originating from 6 non-fasted rats of $140-150 \mathrm{~g}$ body weight, was incubated in $2 \mathrm{ml}$ of Krebs-Ringer bicarbonate buffer (glucose $2 \mathrm{mg} / \mathrm{ml}$ ) over a period of 4 hours at $37^{\circ} \mathrm{C}$ in a Dubnoff metabolic incubator. After dilution with $10 \%$ TCA the media were centrifuged and assayed for glucose in triplicate with anthrone reagent [10].

Each assay involved 5 groups of 4 vessels, 3 groups being used to establish the basal glucose uptake and the response to 12.5 and $50 \mu \mathrm{U} / \mathrm{ml}$ of insulin. The remaining groups served to assess the response to the unknown preparation in the presence and absence of excess guinea pig antibovine insulin serum (neutralizing potency $>2 \mathrm{mU} / \mathrm{ml}$ at final dilution of 1/400) Antiserum was added $40-50 \mathrm{~min}$ prior to incubation.

a) Whole serum was assayed at four-fold dilution after adjusting the glucose concentration to $2 \mathrm{mg} / \mathrm{ml}$. A four-fold dilution was chosen in view of the fact that this was the highest serum concentration to give parallel regression with the insulin standard on further dilution. Basal glucose uptake and the response to standard insulin were determined in buffer containing $1 \%$ of bovine serum albumin.

b) Wet protein fractions were assayed without further dilution immediately after elution from the columns. Basal glucose uptake and two-point standard curves were determined in buffer containing $0.25 \%$ of bovine serum albumin.

c) Dry protein fractions were dissolved in KrebsRinger buffer to a concentration of $8 \mathrm{mg} / \mathrm{ml}$ and assayed in 3-point design in the absence and presence of added antibody. In the case of serum 51119 the fractions were also assayed in 4-point design to establish parallelism with the insulin standard curves.

Radioimmunoassay. The method of Yalow and Berson [18] with slight modifications was used for the immunoassay of whole serum and column fractions. Crystalline bovine insulin (24.9 I.U./mg) was labelled with ${ }^{131} \mathrm{I}$ by the chloramine-T procedure and purified on Sephadex G-75 [3]. Free and antibody-bound tracer hormone were separated by hydrodynamic flow chromatography on Whatman 3-MC paper. Prior to application on paper the protein concentration in the assay system was raised to $8.2-9.8 \mathrm{mg} / \mathrm{ml}$ by adding normal guinea pig serum. Concentrations of antibovine insulin serum and tracer hormone were selected to give about $65 \%$ binding of label without added insulin and a reduction of this percentage with $4-5 \%$ in the presence of $1 \mu \mathrm{U}$ of bovine insulin per $\mathrm{ml}$. Maximum sensitivity of the assay amounted to $0.5 \mu \mathrm{U} / \mathrm{ml}$. Whole serum and wet column fractions were assayed at a final dilution of $1 / 10$, dry protein fractions at final concentrations varying between 0.25 and $2.0 \mathrm{mg} / \mathrm{ml}$. Each sample was assayed in duplicate, a third tube being included to evaluate the effect of the sample on the tracer in the absence of antibody to allow correction for incubation damage. 


\section{Results}

Seperation of exogenous and endogenous insulin from serum proteins

Serum from peripheral blood to which crystalline insulin had been added and pancreatic venous serum were used in pilot experiments to test the ability of our Sephadex columns to separate exogenous and endogenous insulin from the serum proteins. As shown by Figs. 1 and 2, both added, and endogenous immuno-

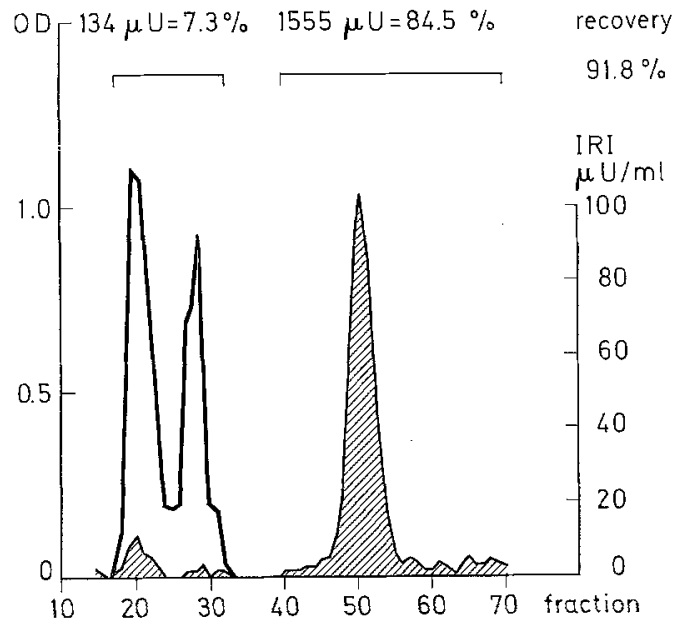

Fig. 1. Separation on Sephadex G-100 of $4 \mathrm{ml}$ of bovine serum following addition of crystalline insulin $(460 \mu \mathrm{U})$ ml). Hatched areas depict the elution pattern of immunoassayable activity. Fraction volume $3.2 \mathrm{ml}$

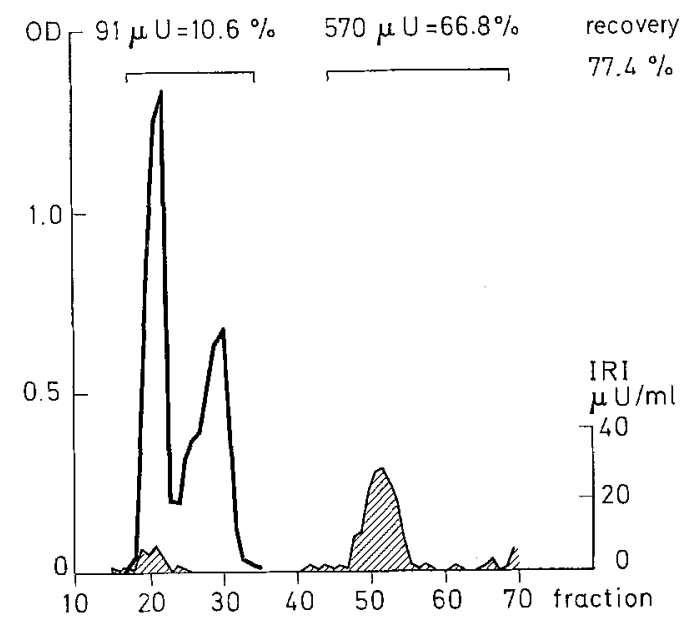

Fig. 2. Separation on Sephadex G-100 of $4 \mathrm{ml}$ of bovine pancreatic venous serum containing $213 \mu \mathrm{U}$ of endogenous IRI per ml. Hatched areas depict the elution pattern of endogenous immunoassayable activity. Fraction volume $3.5 \mathrm{ml}$

reactive insulin (IRI) appeared to be concentrated predominantly in a distinct peak in the low molecular region of the eluate. It should be noted, however, that in both sera some $7-10 \%$ of the initial IRI content was eluted in the first protein peak, which mainly consists of serum globulins. Although the accuracy of this percentage may be questioned in view of limitations imposed by the sensitivity of the assay, the apparent consistency of this phenomenon (see also Fig. 3) should be emphasized.

\section{Serial investigation of serum protein fractions}

Data on a total of 11 non-selected bovine sera have been summarized in Fig. 3. In the 10 sera shown in the left part of the figure, which were designated as normal, the IRI content of the native serum averaged.

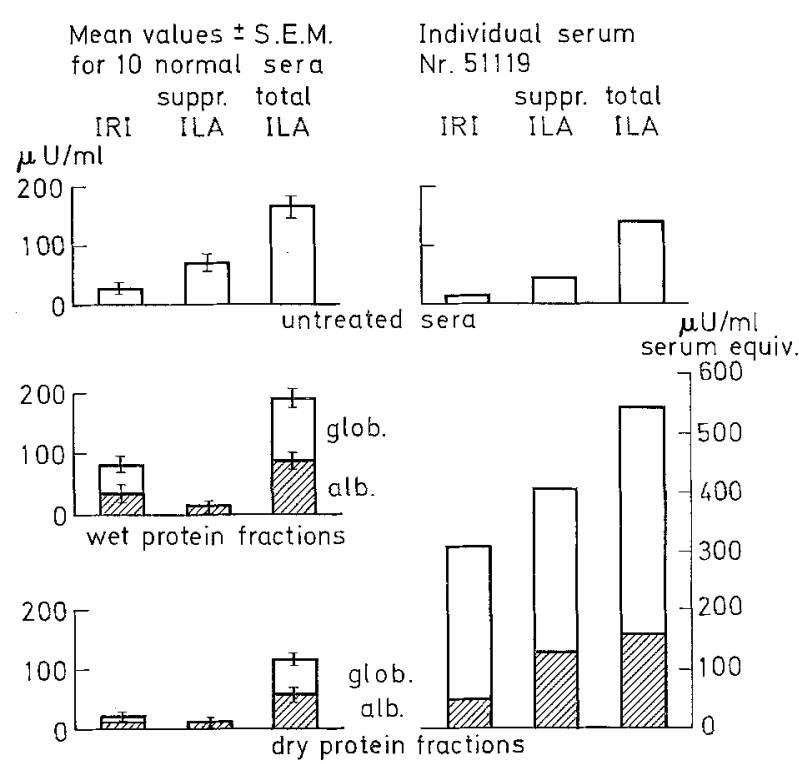

Fig. 3. Immunoassayable activity, total and antibodysuppressible insulin-like activity in 11 bovine sera and serum protein fractions isolated by gel filtration on Sephadex G-100. Values have been expressed in $\mu \mathrm{U}$ per $\mathrm{ml}$ of original serum

$24 \pm 3.5 \mu \mathrm{U} / \mathrm{ml}$. Total ILA as measured by adipose tissue assay amounted to $164 \pm 14 \mu \mathrm{U} / \mathrm{ml}$, of which $67 \pm 11 \mu \mathrm{U} / \mathrm{ml}$ appeared to be suppressible by antiinsulin serum.

To allow direct comparison with the data on whole serum, the activities of the two protein peaks isolated from these sera have been expressed per $\mathrm{ml}$ of original serum, assuming these peaks to contain equal amounts of protein at a total protein content of $65 \mathrm{mg}$ per $\mathrm{ml}$ of serum. In the lyophilized globulin and albumin fractions no significant amounts of IRI or suppressible ILA could be detected, all biologic activity being of the non-suppressible type. When, however, the protein fractions were immunoassayed in the wet state directly after their collection from the column, an average amount of $47 \pm 9 \mu \mathrm{U}$ of IRI per ml of serum was detected in the globulin peak and $36 \pm 10 \mu \mathrm{U}$ per $\mathrm{ml}$ in the albumin-containing fractions.

Expressing these values in this way involves considerable extrapolation on the original assay results in view of the serum dilution which occurs during elution. The minimal detectable level of activity per $\mathrm{ml}$ of serum, obtained by multiplying the dilution factor for 
each protein peak by the lowest concentration of insulin which is detected by our immunoassay system $(0.5 \mu \mathrm{U} / \mathrm{ml})$, amounts to $30 \mu \mathrm{U}$ per $\mathrm{ml}$ of serum for the globulin peak and to $40 \mu \mathrm{U}$ per $\mathrm{ml}$ for the albumin fraction. Taking also into account that in 7 out of 10 sera the IRI content of the globulin peak actually exceeded the corresponding minimal detectable level, the mean activity of $47 \pm 9 \mu \mathrm{U} / \mathrm{ml}$ as observed in this peak would appear to represent a measurable quantity of IRI. The presence of IRI in the albumin peak remains highly questionable, however, since the mean value of $36+10 \mu \mathrm{U} / \mathrm{ml}$ does not exceed the maximum "noise level" for this peak which amounted to 40 $\mu \mathrm{U} / \mathrm{ml}$.

Table 1. Immunoassay of serum protein fractions isolated from serum 51119

\begin{tabular}{|c|c|c|c|c|c|}
\hline & \multicolumn{4}{|c|}{$\mu \mathbf{U} / \mathrm{mg}$ protein } & $\begin{array}{l}\mu \mathrm{U} / \mathrm{ml} \\
\text { serum }^{\mathrm{c}}\end{array}$ \\
\hline Globulin & Batch & Batch & Batch & Mean & \\
\hline fraction & & & & 土S.E.M. & \\
\hline $0.25 \mathrm{mg} / \mathrm{ml}^{\mathrm{a}}$ & $6.8^{b}$ & 8.8 & 9.2 & & \\
\hline $0.5 \mathrm{mg} / \mathrm{ml}$ & 8.0 & 7.8 & 8.6 & $8.0 \pm 0.3$ & $260 \pm 10$ \\
\hline $1.0 \mathrm{mg} / \mathrm{ml}$ & 8.6 & 7.1 & 7.4 & & \\
\hline \multicolumn{6}{|l|}{$\begin{array}{l}\text { Albumin } \\
\text { fraction }\end{array}$} \\
\hline $0.5 \mathrm{mg} / \mathrm{ml}^{\mathrm{a}}$ & - & & 0.8 & \multirow{4}{*}{$1.4 \pm 0.3$} & \multirow{3}{*}{$46 \pm 10$} \\
\hline $1.0 \mathrm{mg} / \mathrm{ml}$ & 1.1 & & 2.3 & & \\
\hline $2.0 \mathrm{mg} / \mathrm{ml}$ & 1.0 & & 2.0 & & \\
\hline Both fractions & & & & & 306 \\
\hline
\end{tabular}

Table 2. Adipose tissue assay of serum protein fractions isolated from serum $\mathbf{5 1 1 1 9}$

\begin{tabular}{|c|c|c|c|c|}
\hline & $\mu \mathrm{U} / \mathrm{mg}$ protein & & $\mu \mathrm{U} / \mathrm{ml}$ se & rumb \\
\hline $\begin{array}{l}\text { Globulin } \\
\text { fraction }\end{array}$ & $\begin{array}{l}\text { Total } \\
\text { ILA }\end{array}$ & $\begin{array}{l}\text { Suppr. } \\
\text { ILA }\end{array}$ & $\begin{array}{l}\text { Total } \\
\text { ILA }\end{array}$ & $\begin{array}{l}\text { Suppr. } \\
\text { ILA }\end{array}$ \\
\hline $\begin{array}{l}\text { 4-point assays } \\
\text { (batch } 1 \text { ) } \\
\text { 3-point assays } \\
\text { (batch } 2 \text { ) }\end{array}$ & $\begin{array}{r}11(8.1-15.2)^{2} \\
14(10.7-18.6) \\
8 \\
15\end{array}$ & $\begin{array}{r}6 \\
11 \\
\end{array}$ & & \\
\hline $\begin{array}{l}\text { Mean } \pm \text { S.E.M. } \\
\text { Albumin } \\
\text { fraction }\end{array}$ & $\overline{12} \pm 1.6$ & $\overline{8} .5$ & $390 \pm 52$ & 276 \\
\hline $\begin{array}{l}\text { 4-point assays } \\
\text { (batch 1) } \\
\text { 3-point assays } \\
\text { (batch 2) }\end{array}$ & $\begin{array}{l}4(2.6-5.3) \\
4(2.5-7.1) \\
7 \\
3\end{array}$ & $\begin{array}{l}6 \\
2 \\
\end{array}$ & & \\
\hline $\begin{array}{l}\text { Mean } \pm \text { S.E.M. } \\
\text { Both fractions }\end{array}$ & $4 . \overline{5} \pm 0.9$ & $\overline{4}$ & $\begin{array}{l}146 \pm 29 \\
536\end{array}$ & $\begin{array}{l}130 \\
406\end{array}$ \\
\hline
\end{tabular}

a $95 \%$ confidence limits

b Assuming serum to contain $65 \mathrm{mg} / \mathrm{ml}$ of protein equally divided over the two protein fractions

\section{Serum 51119}

One serum (51119) which gave highly discrepant results when compared with the other ten, was in- vestigated more extensively. Two independent batches of dry serum proteins were isolated from this serum, freshly prepared sets of columns being used on both occasions. The first batch of proteins was obtained from $20 \mathrm{ml}$ of serum in two successive runs on two columns, whereas the second batch originated from $60 \mathrm{ml}$ of the serum which was separated two months later in six double runs. Separate data on each of these batches are given in Tables 1 and 2 .

Table 1 shows the results obtained by radio-immunoassay of the dry protein fractions at three different concentrations. Immunoassayable activity in the globulin fraction averaged $8.0 \pm 0.3 \mu \mathrm{U}$ per $\mathrm{mg}$, whereas the albumin fraction contained $1.4 \pm 0.3 \mu \mathrm{U} / \mathrm{mg}$. The possibility that these results were due to nonspecific interference with the reaction between antibody and labelled hormone was ruled out by setting up standard curves in the presence of varying concentrations of the protein fractions in the assay system. Parallel standard curves were obtained in each case (Fig. 4).

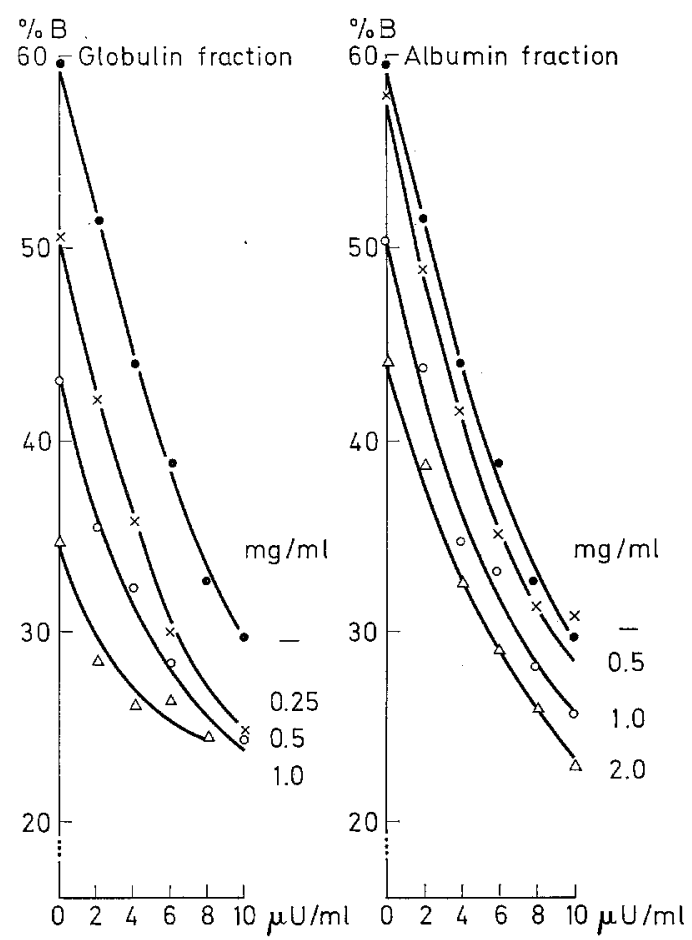

Fig. 4. Standard curves for crystalline insulin at various concentrations of dry protein fractions from serum 51119 in the immunoassay system

The activity of the fractions on adipose tissue in vitro is demonstrated by Table 2 . Total ILA determined both in replicate parallel-line and 3-point assays averaged $12 \pm 1.6 \mu \mathrm{U} / \mathrm{mg}$ for the globulin fraction and $4.5 \pm 0.9 \mu \mathrm{U} / \mathrm{mg}$ for the albumin fraction. The antibody-suppressible activity in these fractions amounted to 8.5 and $4 \mu \mathrm{U} / \mathrm{mg}$ respectively, the latter values 
closely approaching those found by radioimmunoassay.

On the basis of these results, the combined globulin and albumin fractions of serum 51119 can be calculated to have contained $306 \mu \mathrm{U}$ of immunoassayable activity per $\mathrm{ml}$ of original serum and $406 \mu \mathrm{U}$ of antibody-suppressible ILA (Fig. 3, right side). These values exceed those obtained by direct assay of the native serum by a factor of about ten, its IRI content and suppressible ILA being $15 \mu \mathrm{U} / \mathrm{ml}$ and $46 \mu \mathrm{U} / \mathrm{ml}$ respectively. The latter activities fall in the range of the other native sera investigated. It should be stressed, that all assays on serum 51119 in the native state were conducted after isolation of the serum protein batches.

\section{Discussion}

When bovine pancreatic venous serum was passed through Sephadex G-100, endogenous IRI was eluted for the greater part as a low molecular weight substance, comparable with added erystalline insulin. The recovery of $66-88 \%$ of the initial IRI content in this fraction is in excellent agreement with studies on dog pancreatic venous serum separated on Sephadex G-50 [12], and on ultracentrifuged human plasma following glucose loading [5]. Taking also into account that the ILA in low molecular serum fractions is of the antibodysuppressible type $[11,12,13]$, there can be little doubt that in normal plasma or serum containing high levels of endogenous IRI, insulin is predominantly present in the form of a free and relatively small molecule, which can be separated from the serum proteins on the basis of its size.

The present study and various data from the literature, however, make it highly questionable whether this conclusion may be extrapolated to sera with low fasting levels of IRI. Our wet globulin fractions from 10 random sera with an IRI content of $24 \pm 3.5 \mu \mathrm{U} / \mathrm{ml}$, were found to contain $47 \pm 9 \mu \mathrm{U}$ of IRI per ml of serum. The latter value not only would exceed the minimal detectable levels of IRI in such fractions, but also the IRI content of the native serum, which is the more remarkable if one assumes that gel filtration did actually exclude small size IRI from the protein moiety.

Small amounts of IRI $(7-14 \mu \mathrm{U} / \mathrm{ml}$ of serum) in gel-filtered serum protein fractions have also been reported by Kajinuma et al. [12], but no further attention was given to this finding in view of the absence of suppressible ILA in these fractions. The latter phenomenon, which was also observed in the present study, can be fully explained by the relative insensitivity and inaccuracy of adipose tissue assays compared with radioimmunoassay. Considering the mean lambda of 0.13 of our adipose tissue assay and the total ILA content of the globulin fractions, suppressible activity in these fractions should exceed $40 \mu \mathrm{U} / \mathrm{ml}$ of serum at least to become detectable with the inaccuracies characteristic for this assay. The lack of immunologic activity in our dry globulin fractions is less clear, although this would already be accounted for by a $30 \%$ loss of activity during the procedures of dialysis and concentration.

Results strikingly similar to ours have also been obtained by Kipnis and Stein [13] in a study on five human plasmas with a mean IRI content of $42 \mu \mathrm{U} / \mathrm{ml}$. Following ultracentrifugation $32 \mu \mathrm{U}$ of IRI was detected in the supernatant, whereas an additional 52 $\mu \mathrm{U} / \mathrm{ml}$ of serum was recovered in the protein layer. Again, the reported lack of detectable amounts of suppressible ILA in this fraction is not surprising. Current adipose tissue assays do not allow the detection of $5 \%$ suppressible activity at a total ILA content of about $1100 \mu \mathrm{U} / \mathrm{ml}$ of serum as found in this fraction.

We believe that these findings furnish suggestive evidence for the existence of a high molecular form of IRI in quantities which equal or even surpass the directly assayable IRI content of fasting serum or plasma. Since the plasma insulin response to glucose loading is mainly reflected in the low molecular IRI fraction $[5,12]$, the relative significance of high molecular IRI would seem to be restricted to fasting conditions. Obviously, its possible physiological significance remains to be established. In this connection, it may be relevant that appearance of antibody-suppressible ILA has been observed in serum globulin fractions, isolated by gel filtration on Sephadex G 200 , after dialysis for 48 hours at $37^{\circ} \mathrm{C}$ against $1 \mathrm{mM} \mathrm{CaCl}$ at $\mathrm{pH} 7.7-8.1$ [11].

The remarkable properties of the aberrant serum 51119 may lend additional support to the views expressed above. Whereas assays performed on the native serum gave values closely approaching those observed in the other sera, the gel-filtered protein fractions were found to contain $306 \mu \mathrm{U}$ of IRI per ml of serum, of which $260 \mu \mathrm{U}$ appeared to reside in the globulin fraction. Roughly equivalent amounts of suppressible ILA were found in the bioassay of these fractions. The validity of these results was confirmed by replicate assays on two independently isolated batches of serum proteins and by additional control experiments. It would seem, therefore, that under certain conditions the serum globulin fraction may actually contain considerable amounts of IRI, its presence in the native serum being masked by some unknown mechanism.

In view of the controversial nature of these results, the possibility of accidental contamination with crystalline insulin deserves serious attention. Theoretically, contamination might have oceurred either prior to, during or after the isolation of the serum protein fractions. The first of these possibilities can be ruled out, since all assays on the native serum were performed after the isolation of the second batch. Moreover, contaminating insulin would have behaved like a low molecular weight substance (Fig. 1). Contamination of the Sephadex gel can also be excluded since new 
columns were prepared for the isolation of each batch. Contamination of the elution buffer would have caused equally distributed activity in both protein fractions, which was not the case. Thirdly, no plausible reason can be given for assuming that contaminated glassware could be responsible for an unequally distributed and reproducible degree of contamination of globulin and albumin fractions from different size batches which were isolated with an interval of two months.

The apparent presence of a masked form of high molecular IRI in serum 51119 poses many questions, which cannot be answered at present. Unmasking of this activity apparently occurred during gel filtration or any of the subsequent preparative procedures such as freeze-drying or dialysis against water. The results of the adipose tissue assay furthermore suggest that the high molecular activity was biologically inactive in its native state. Definite proof for this is lacking since the untreated serum was not tested for insulin antagonism on adipose tissue. The presence of a neutralizing immune-globulin in this serum can be ruled out, however, since the labelled bovine insulin in our immunoassay system did not complex with the serum proteins in the absence of anti-insulin serum.

Little can be said on the nature of high molecular IRI in serum. Since this material mainly resided in the globulin fraction with a molecular weight of 100000 at least, the presence of insulin polymers, proinsulin or the "big insulin" described by Roth et al. [15] seems highly unlikely. The most obvious explanation therefore would be that the activity resided in a protein complex. The existence of a protein-bound form of insulin in serum has been postulated by Antoniades et $a l$. [1], but the experimental evidence in support of this concept has been severely criticized $[6,7,13,19]$. Attempts to demonstrate the presence of IRI in ionexchange-resin fractions prepared according to Antoniades, have so far remained unsuccessful. This argument cannot be raised against the high molecular activity observed by us. The activity in serum 51119 appears to meet three minimum criteria for endogenous insulin as defined in the introduction of this paper.

The underlying cause of the aberrant properties of serum 51119 remains unclear. In view of the suggested presence of small quantities of high molecular IRI in random normal sera, it is tempting to speculate that the difference was mainly quantitative thus representing an exaggerated picture of a basically normal pattern. Whether this might be due to a pathologic condition remains conjectural, since further data on the cow from which serum 51119 originated are lacking.

The possible significance of these findings is further supported by our recent observation that milli-Unit quantities of high molecular IRI can be generated in the globulin fraction of any normal serum by briefly incubating the serum with orystalline insulin at $37^{\circ} \mathrm{C}$. This phenomenon is facilitated by the presence of small amounts of liver homogenate [9]. Generated high molecular IRI is biologically active both in vivo and in vitro and appears to dissociate rapidly into IRI of a molecular size similar to that of crystalline insulin.

Acknowledgements: The authors are greatly indebted to Dr. A.W. Kersjes of the Department of Veterinarian Surgery of the University of Utrecht for the collection of bovine pancreatic venous blood and to Dr. P. Krediet of the Department of Anatomy of the Medical Faculty of Rotterdam for his valuable advice in planning the surgical approach.

\section{References}

1. Antoniades, H.N., Gundersen, K., Beigelman, P.M., Pyle, H.M., Bougas, J.A. : Studies on the state, transport and regulation of insulin in human blood. Diabetes 11, 261-270 (1962).

2. - Huber, A.M., Boshell, B.R., Saravis, C.A., Gershoff, S.N.: Studies on the state of insulin in blood. Properties of circulating "free" and "bound" insulin. Endocrinology 76, 709-721 (1965).

3. Banerjee, R.N., Gibson, K.: Preparation and purification of high specific activity insulin- ${ }^{131}$ Iodine. J. Endoer. 25, 145-146 (1962).

4. Berson, S.A., Yalow, R.S.: Plasma insulin in health and disease. Amer. J. Med. 31, 874-881 (1961).

5. - Immunoassay of plasma insulin. In: Immunoassay of Hormones. Ciba Foundation Colloquia on Endocrinology, vol. XIV, pp. 182-201. Ed. G.E.W. Wolstenholme and M.P. Cameron. London: J. \& A. Churchill 1962.

6. - Bound insulin-fact, fancy or phantasy - Second International Congress on Endocrinology, London, 1964. Excerpta Medica Internat. Congress Series No. 83 , pp. $332-337$.

7. - Some current controversies in diabetes research. Diabetes 14, 549-572 (1965).

8. - Insulin in blood and insulin antibodies. Amer. $J$. Med. 40, 676-690 (1966).

9. Bouman, P.R.: International Symposium on Protein and Polypeptide Hormones, Liège, 1968. Excerpta Medica Internat. Congress Series No. 161, part 3, pp. $582-584$.

10. - Dermer, W.: Effects of adrenaline on carbohydrate metabolism in the isolated diaphragm of intact and adrenalectomized rats as influenced by nembutal anaesthesia. Acta endocr. (Kbh) 35, 541-550 (1960).

11. Gjedde, F.: Studies of the insulin-like activity of serum. II: Characterization of insulin-like activity of serum protein fractions from normal human subjects. Acta endocr. (Kbh) 57, 478-504 (1968).

12. Kajinuma, H., Ide, T., Kuzuya, T., Kosaka, K.: Insulin-like activity by fat pad assay and immunoreactive insulin. II: Their occurrence in fractions by gel filtration of serum. Diabetes 18, 75-83 (1969).

13. Kipnis, D.M., Stein, M. F.: Insulin antagonism : fundamental considerations. In: The Aetiology of Diabetes Mellitus and its Complications. Ciba Foundation Colloquia on Endocrinology, vol. XV, pp. 156-184. Ed. M.P. Cameron and M. O'Connor. London: J. \& A. Churchili, 1964.

14. Meade, R.C., Stiglitz, R.A., Kleist, T.J.: The state of pancreatic and serum insulin. Results of immunoassay. Diabetes 14, 387-391 (1965).

15. Roth, J, Gorden, Ph., Pastan, I.: "Big insulin": a new component of plasma insulin detected by immunoassay. Proc. nat. Acad. Sci. 61, 138-145 (1968). 
16. Steelman, S.L., Oslapas, R., Busch. R.D.: An improved in vitro method for determination of serum "insulin-like" activity. Proc. Soc. exp. Biol. 105. $595-598(1960)$.

17. Umbreit, W.W., Burris, R.H., Stauffer, J.F.: Manometric Techniques, 3rd ed. p. 149. Minneapolis: Burgess Publishing Co. 1957.

18. Yalow, R.S., Berson, S.A.: Immunoassay of endogenous plasma insulin in man. J. clin. Invest. 39, $1157-1175(1960)$.
19. - The significance of ILA. Sixth Congress of the International Diabetes Federation, Stockholm 1967. Excerpta Medica Internat. Congress Series No. 172, pp. $233-237$.

W. Konijnendijk

Department of Pharmacology

University of Groningen

1 Bloemsingel, Groningen

The Netherlands 